УДК 821.161.1.09:1(470)(092)

Сабат Г. П.

доктор філологічних наук, професор Дрогобицький державний педагогічний університет імені Івана Франка

\title{
«БРАТИ КАРАМАЗОВИ» Ф. ДОСТОЄВСЬКОГО ТА «МИ» \\ Є. ЗАМЯТІНА: СУГОЛОСНІСТЬ ФІЛОСОФСЬКИХ КОНЦЕПЦІЙ
}

У статті досліджується вплив філософських поглядів Ф. Достоєвського на провідні образи та мотиви, зокрема сакральні, у творах Є. Замятіна. Особливий тип художньої изілісності виявлений на жанротворчих рівнях сюжетно-проблемної, композиційної організачї̈, еволючї̈ образів героїв, зображально-стильової єдності у порівняльному зіставленні.

Ключові слова: утопія, антиутопія, роман, жанр, майбутнє.

В статье исследуется влияние философских взглядов Ф. Достоевского на ведущие образы и мотивы, в частности сакральные, в произведениях Е. Замятина. Особый тип художественной целостности выявлен на жанротворческих уровнях сюжетно-проблемной, композиционной организации, эволющии героев, изобразительно-стилевого единства в сравнительном сопоставлении.

Ключевые слова: утопия, антиутопия, роман, жанр, будущее.

The article deals with the study of influence of philosophical views of F. Dostoyevvskii on main sacred images and motives in literary works of Ye. Zamyatin. A specific type of artistic integrity is revealed on the genre-creating levels of the plot - problematic compositional organization of the work, the evolution of the images of characters the expressive stylistic integrity in comparison.

Key words: utopia, antiutopia, romance, genre, future. 
У 1924 році, слідом за революційними подіями і воєнним комунізмом у Росії, був опублікований роман С. Замятіна «Ми». Письменник передбачив, що зовні привабливі утопійні ідеї про планово організоване, всезагально єдине колективне ціле призведуть до страхітливого тоталітарного режиму, який знівечить, знівелює, спотворить і знищить людину як особистість. Звичайно, на батьківщині письменника роман не сприйняли, назвали «наклепом на революцію», адже Є. Замятін показав, що ідеї революції спричинять катастрофу.

На нашу думку, в смисловому відношенні попередником Свгена Замятіна був Федір Достоєвський. Наголосимо на постійному замятінському інтересі до творчості Ф. Достоєвського, емоційне сприйняття якого ще в дитинстві вплинуло на подальше творче життя. «Досі пам’ятаю тремтінння від “Нєточки Незванової“», - зафіксовано в «Автобіографії» (1924). Неодноразово Є. Замятін згадує ім'я Достоєвського у своїх літературно-критичних статтях 20-х років «Про синтетизм», «Про літературу, революцію, ентропію й інше», «Про сьогоднішнє і сучасне», «Герберт Веллс», «У за кулісах». Відзначимо статтю, присвячену творчості Г. Веллса, в якій С. Замятін концентрується на генологічній проблематиці, порівнюючи художньо-естетичні форми обидвох письменників: «У своїй галузі - зрозуміло, в пропоризійно меншому масштабі Уеллс зробив те саме, щзо й Достоєвський, який взяв форму бульварного, кримінального роману $i$ об’єднав ц̧ю фрорму з геніальним психологічним аналізом» [Замятин $1988: 391]$.

Роман Г. Веллса «Машина часу» ознаменував початок періоду розквіту антиутопії, що нещадно розвінчує невиразні ідеали утопістів, моделює жахливі наслідки їх реалізації. Г. Веллс створив оригінальну концепцію майбутнього суспільства та його модель, продовживши традиції утопії і водночас відкрив нове, що відіграло важливу роль у становленні антиутопії. У літературознавстві утвердилася думка, що основоположник світової антиутопії Є. Замятін. Без його «Ми», ймовірно, не було $б$ ані «Чудового нового світу» О. Гакслі, ані «1984» Дж. Орвелла. 
Для змісту роману «Ми» важлива рецепція філософських ідей Ф. Достоєвського із твору «Брати Карамазови». «Ми» пронизує ідея примусового щастя, яка бере свої витоки із «Легенди про великого інквізитора» Ф. Достоєвського - вставної новели-сповіді з «Братів Карамазових». Віра в таке щастя грунтувалася на доктрині відмови від свободи, а рай для всіх будувався на іiі придушенні. М. Павлова-Сільванська вже на початку своєї статті «Це солодке “ми”, це підступне “ми”ставить риторичне питання: «Чи не писав він (С. Замятін. - Г. С.) з самого початку інтелектуальну арабеску? Чи не була його книга вільною грою розуму, варіацією на теми Достоєвського?» [ПавловаСильванськая: 1988 : 260].

У романі Ф. Достоєвського «Брати Карамазови» $\epsilon$ образ великого інквізитора, який силою хоче змусити людей бути щасливими шляхом злиття в єдиний, бездоганний, згідливий мурашник. Цей образ мав чималий вплив на Є. Замятіна, недарма великий інквізитор і Благодійник із роману «Ми» мають так багато спільного. Великий інквізитор - дев’яностолітній дід 3 висохлим обличчям, із запалими очима, але він володіє необмеженою владою, його волю люд негайно виконує без вагань. Згадаймо епізод, коли приходить Господь i зцілює сліпого, оживляє дівчинку, народ співає йому хвалу, цілує ноги. Але раптом велично приходить великий інквізитор, він усе бачив і наказує варті взяти Господа: «I ось, така його сила ц̆ до того вже привчений, скорений $i$ тремтливо слухняний йому народ, щзо натовп негайно розступається перед вартою, $i$ ті, серед могильного мовчання, раптово запалого, накладають на нього руки й виводять його» [Достоевский 1981 : 282].

В Є. Замятіна Благодійник уже своїм зовнішнім виглядом нагадує ідола: «Тяжкий, камінний, як доля, Благодійник...» [Замятин 1988 : 34], у нього «нерухома, як із металу, фігура» [Замятин 1988 : 32]. Не випадково Д-503 боїться підняти голову до нього, а у своєму щоденнику займенники, якими називає Благодійника, пише з великої літери.

Машина Благодійника в романі С. Замятіна - це символ смерті й знищення. А «чавунні руки» Благодійника - знак караючої сили. Саме вони 
натискають на важіль машини, щоб покарати непокірного. Відповідно, автор підбирає стилістично-вартісні епітети, що підсвічують закладену ідею: вони «кам’яні», «тяжкі», «заслоняють собою все», їх жест «чавунний» [Замятин 1988 : 32]. Письменник використовує аналогії, які виразніше окреслюють образ: «Опам’ятався - уже стояв перед Ним, і мені страшно підняти очі: бачу лише Його величезні, чавунні руки - на колінах. Ці руки тиснули його самого, підгинали коліна. Він помало рухав пальцями» [Замятин 1988 : 141].

У зовнішності Благодійника автор виділяє руки як знаряддя покарання. У наведеному прикладі доречним видається і порівняння Благодійника 3 павуком, що максимально увиразнює образ, дає вичерпну психологічну оцінку. Символічний образ мудрого «Павука» пов'язується 3 Благодійником не випадково. Саме він знаходиться в центрі могутньої ідеологічної машини, тому й осмислюється як павук, що павутиною одурманювання, брехні обплутує всіх громадян Сдиної Держави. Таку роль керманича-диктатора вони сприймають як щастя, що передається через емоційно виражене спостереження головного героя твору: «I в изентрі ї̈ - зараз сяде білий, мудрий Павук - у білих одежах Благодійник, щзо мудро зв'язав нас по руках $i$ ногах благодійними тенетами щзастя» [Замятин 1988 : 94]. Аналогію між павуком і людиною автор проводить 3 метою затаврувати тоталітарну владу.

До вершин соціальної сатири піднімається Є. Замятін у змалюванні Дня Сдиноголосування. Сорок восьмий раз зібралися громадяни Сдиної Держави, щоб знову вибрати своїм керманичем Благодійника. Перед очима читача розгортається цинічна комедія: мільйони "нумерів“" вкотре беззаперечно піднімають руки “за“, слухняно виконуючи волю Благодійника i його "Оберігачів". Раптом свято затьмарює «якесь замімання, викликане ворогами щуастя, котрі тим самим, звичайно, позбавили себе права стати цеелинами оновленого вчора фундаменту Сдиної Держави. Будь-кому зрозуміло, щуо зарахувати їхні голоси було би так само безглуздо, як прийняти за частину чудової, героїчної симфонії - кашель випадково присутніх у концертному залі хворих...» [Замятин 1988 : 99]. 
У романах Є. Замятіна i Ф. Достоєвського виникає конфлікт між особистістю і суспільством, який базується на одвічному зіткненні свободи i щастя. Великий інквізитор прагне вдруге розіп'яти Христа, щоб він не заважав людям єднатися в загальному мурашнику й не баламутив їхній розум думками про свободу. Церковний служитель вперше за дев'яносто років оголює душу перед полоненим: «Говорю тобі, щчо нема в людини турботи нестерпнішої, як знайти того, кому би передати якнайтвидше той дар свободи, з яким ия нещасна істота народжується. Але оволодіє свободою людей лише той, хто заспокоїть їхню совість. Із хлібом тобі давалось безперечне знамено: даєи хліб і людина прихилиться, бо нічого нема безперечнімого хліба, але якщо в той же час хто-небудь оволодіє його совістю поза тобою - о, тоді він навіть кине хліб твій $і$ niде за тим, хто облестив його совість» [Достоевский 1981 : 288]. Великий інквізитор i Благодійник уміло уярмлюють своїх підлеглих, перетворюючи їх у череду „нумерів”-рабів. Вони регулюють їхні почуття, життєвий уклад, i зрештою - питання про свободу особистості перестає існувати.

Проблема щастя у творі Є. Замятіна вирішується як і у Ф. Достоєвського: людська особистість не стоїть перед вибором - бути щасливою чи ні, іï змусили бути щасливою (у свідомість людини постійно насаджується абстрактне штучно-радісне відчуття). Антиутопісти слідом за Є. Замятіним продемонструють, як в ім'я “всезагального щастя“" приносяться в жертву величезні маси, знищують усіх, хто не хоче стати на шлях примусового щастя. Людину прагнуть зробити щасливою, нав'язавши їй стандартне для всіх, знеособлене щастя. Письменники доводять, що державне насильство не може зробити окремого індивіда заплановано щасливим. Така тиранія, викликає протест у головних героїв антиутопій. Футурологи не можуть змиритися 3 тим, що ідеал всезагальної досконалості й щастя не досягається без тиранії. Усе, що підігнано силоміць, не дає позитивного ефекту, не може бути визнаним як благо. Чи потрібне людині таке щастя, яке не обходиться без насильства? 
Таким чином, в «Легенді про великого інквізитора» й романі «Ми» на терези поставлені категорії «щастя» і «свобода».

Сам Ф. Достоєвський часто свідчив, що задумував „Легенду” як кульмінацію «Братів Карамазових». Так, в листі М. Любімову від 10 травня 1879 р. він заявляє: «...ияя 5-та книга за моїм переконанням є кульмінаційною точкою роману» [Чешихин-Ветринский 1923: 133-134]. Через кілька днів у листі до П. Побєдоносцева повторює: «Справа в тому, щзо ияя книга в романі в мене кульмінаційна, називається "Pro $i$ contra"» [Чешихин-Ветринский 1923 : 135]. I насамкінець, повідомлення В. Пуциковича: «Федір Михайлович 3 цุією легендою - про Великого інквізитора - досягнув кульмінаційного пункту в своїи літературній творчості... На моє ж питання, щзо означає те, щзо він помістив саме таку релігійну легенду в роман з російського життя («Брати Карамазови»), і чому саме він вважає не сам роман, який мав такий успіх щуе до його закінчення, важливим, а цุю легенду, він пояснив мені ось щзо. Він тему цієї легенди, так би мовити, виношував у свойй душі майже протягом усього життя $і$ бажав би саме тепер пустити в хід, оскільки не знає, чи вдасться йому ще щуо-небудь вагоме надрукувати» [Чешихин-Ветринский 1923: 159-160].

Отже, Ф. Достоєвський і Є. Замятін закликали не допустити розриву між особистістю та іï призначенням, застерігали від антигуманності, схематизму, стандартизації, духовної убогості. Вони остерігали людство в надії, що йому вдасться не допустити цих помилок. Ф. Достоєвський прагнув розібратися в людській душі, він фіксував гостре зіткнення полюсів добра i зла, концентрувався на духовно-моральній стороні. Максим Горький, який не сприймав творчості Достоєвського (як і пізніше - творчості С. Замятіна), все ж у листі до Чехова в травні 1899 р. зазначав: «Як дивно, щзо в могутній російській літературі нема символізму, нема цьього прагнення трактувати питання корінні, питання духу... у нас лише Достоєвський посмів написати «Легенду про великого інквізитора» - i все!» [Горький 1937: 27-28]. Художню сміливість Ф. Достоєвського підняти «питання корінні, питання духу» продовжить С. Замятін у романі-пересторозі «Ми», символічній антиутопії. 


\section{БІБЛІОГРАФІЯ}

Достоевский 1981 - Достоевский Ф.М. Братья Карамазовы. - М. : Современник, 1981. - Ч. I, II.

ПСВ 1937 - М. Горький и А. Чехов. Переписка, статьи и воспоминания. М.-Л., 1937.

Замятин 1988 - Замятин Е. Я боюсь // Лит. обозрение. - 1988. - № 2.

Замятин 1988 - Замятин Е.И. Мы // Избранное. - М.: Правда, 1989.

Замятин 1988 - Замятин Е.И. Сочинения. - М.: Книга, 1988.

Павлова-Сильванская 1988 - Павлова-Сильванская М. Это сладкое „мы”, это коварное „мы” // Дружба народов. - 1988. - № 11.

Чешихин-Ветринский 1923 - Чешихин-Ветринский В. Е. Ф. М. Достоевский в воспоминаниях современников и его письмах. - М., 1923. - Ч. 